\title{
HARDLY A WASTELAND: ANTIQUITY AND ACADEMIC PRODUCTION IN THE SR OF MACEDONIA
}

\begin{abstract}
This paper examines the problem of academic production of works on Ancient Macedonia in the period of the SR of Macedonia. While it is obvious that the production was not satisfactory - at least not in quantity - it is maintained that the interest for Classical Antiquity was not suppressed, as some might argue; this can best be seen by the publication of Ziva Antika, whose role and importance in the promotion of classical studies must not be taken lightly. At the same time, it is shown that the neglect of ancient Macedonia in the academic circles, especially prior to the rule of Philip II, was in no way restricted to the Macedonian and Yugoslav historical production.
\end{abstract}

Key words. - Živa Antika, M. Petruševski, F. Papazoglu, Ancient Macedonia.

This paper was first delivered back in $2014,{ }^{1}$ at a time when there was an ongoing revision of history and historiographical production, especially concerning the period when the state was part of Yugoslavia. One of the main thrusts in this revisionist movement was the notion that the study of ancient Macedonia was allegedly incompatible with "the idea of brotherhood and unity of the (South) Slavic nations", and accordingly, an extremely important aspect of the history of the Macedonian people was supposedly ignored. Neither then, nor now is my intention to fully challenge this "problem"; I would rather point out certain elements that were quite conveniently ignored in the debate, even though they shed a different light on the question. In that context, I hope I will be let off for restating a number of arguments that are quite self-evident (at best) or even trivial (at worst), since the whole debate rested on ignoring them. Though a number of years have passed and the debate seems to have somewhat abated since then, for two reasons I decided, somewhat reluctantly, that publishing this paper may not be out of place after all: firstly, because even though this discussion may not be as acute as it once was, it is by no means settled and

${ }^{1}$ As a part of the project Repräsentationen des sozialistischen Jugoslawien im Umbruch: Entwicklungen seit den 1970er Jahren, led by Humboldt University in Berlin, under the title "Les grand pères ont toujours tort". 
completely forgotten; and secondly, since a significant part of the paper deals with the importance of Ziva Antika, it is perhaps not an unsuitable topic for the $70^{\text {th }}$ issue of the journal.

In that context, the aim of this paper is twofold: on the one hand, to re-examine the notion that the history of ancient Macedonia and antiquity in general was indeed neglected; on the other, to point out some extenuating circumstances that have usually been ignored. Hence the focus of the research is the historiographical production dedicated to antiquity, with emphasis on the scholarly journal Živa Antika/Antiquité vivante. The publication of the journal started in 1951, on the initiative of professor M. Petruševski, ${ }^{2}$ on whose importance more will be said later in the text. The editorial board was comprised of distinguished scholars from the Yugoslav republics, ${ }^{3}$ and starting from 1999 includes scholars from outside the region.

The revisionist argument is that in the SR of Macedonia the history of ancient Macedonia and ancient history in the RM as a whole were "victims" of an ideological and political system, whose priorities did not lay in the study of the distant past as a research subject. This explanation is oversimplified and one-sided, and therefore calls for a re-examination. Needless to say, the intention is not to disregard the political and ideological context, which, when it comes to the historiographical production, is obviously rather important; ${ }^{4}$ nor to un-critically glorify the academic production of the SR of Macedonia. Yet, the examples are few, if any, where a historical process or condition can be explained by a single cause. Therefore, in order to define the problem in a proper fashion, it is necessary to take into account all the factors that influenced the relatively slow development of the study of ancient Macedonia.

1. First, a word or two about the prevailing notion that the study of ancient Macedonia was completely neglected in the SR of Macedonia. As the authors of one survey published a decade ago point out, ${ }^{5}$

2 Though Petruševski himself admits that the initial idea for establishing a journal came from the two distinguished Serbian philologists and scholars, M. Budimir and M. N. Đurić (ŽA 10 (1960): 4). Basic information concerning Petruševski's life and career can be found in $\check{Z} A 21.1$ (1971), $\check{Z} A 31$ (1981), and $\check{Z} A 40$ (1990).

${ }^{3}$ The first board of editors in 1951 was comprised of Dr. M. Budimir (University in Belgrade), Dr. N. Majnarić (University in Zagreb), Dr. M. Grošelj (University of Ljubljana) and Dr. M. Petruševski (University in Skopje) - all distinguished philologists and leading authorities of the time.

${ }^{4}$ In that context, see the illuminating remarks by prof. H. Melovski, in his interview given for the weekly magazine Пулс 106 (28.01.1993), especially on the problem of self-censorship among historians.

${ }^{5}$ K. Kolozova, M. B. Panov \& I. Milcevski: The nation-state and the institutions of academic knowledge: production and legitimating of dominant discourses oflon knowledge about society - research paper, Euro-Balkan Institute, 2009. I would like to point out that the following discussion is not directed against the authors and their observations. They are cited simply for sake of convenience, since they have gathered the relevant data. 
with the exception of the forty or so pages in the $1^{\text {st }}$ volume of the History of the Macedonian people, published in 1968, in the course of approximately fifty years, almost nothing was written about ancient Macedonia. Though the assessment of the authors is not incorrect, it is perhaps somewhat misleading, and based on the traditional view of history. Indeed, very few (if any) papers can be found that are concerned with the political, administrative or economic history of the ancient Macedonian kingdom. ${ }^{6}$ And yet, if we accede that any and every form or expression of the human experience and action should be (and in fact is) a subject for historical analysis and study, then the conclusion that there was no research or published works concerning ancient history, and the history of ancient Macedonia in particular, does not correspond to the factual situation.

However, if we take into account the contemporary perceptions on the importance and necessity of an interdisciplinary approach to the study of the past, then we are in for a surprise. Of course, the first thing that comes to mind is the already mentioned journal Živa Antika and its seven decades of tradition. The first issue of $\check{Z} A$ opens with a short article by the renowned Yugoslav scholar M. Budimir, ${ }^{7}$ who talks about the motives and the long term aims that stood behind the creation of the journal. ${ }^{8}$ Understandably, the values and the ideals of the socialist order, as well as the importance of the study of the mediaeval Slavic history, are several times highlighted in the text. Nonetheless, at the same time, the author insists on the great need for the study of classical antiquity in the Balkans and primarily for its universal values in European civilization. Just as important, he emphasizes the importance of meticulousness and attentiveness to even the smallest of details, as a prerequisite for the methodical validity of the research. Though these inferences may seem trivial at first glance, if we take into account the width and almost encyclopedic knowledge of the first editors and authors in the journal since its beginnings, and compare them with some of the contemporary historiographical production in the Balkans, we may regretfully conclude that the latter have forgotten "the lessons" of their predecessors.

The international repute of Živa Antika, attained not long after the commencement of its publication, testifies to the quality of the papers published in the journal. ${ }^{9}$ Surely the clearest proof of this assess-

${ }^{6}$ Obviously in this case I am mostly concerned with the papers written by Macedonian scholars, and especially during the first decades of the SR of Macedonia.

${ }^{7}$ For M. Budimir and his distinguished place among the Yugoslav scholars, see: $\check{Z} A$ 21.2 (1971) and $\check{Z} A 26.1$ (1976).

${ }^{8}$ M. Budimir, "Živa antika”, $\check{Z} A 1.1$ (1951): 3-5. cf. Id., "Dvadeset godina Žive Antike", $\check{Z} A 20$ (1970): 3-4.

${ }^{9}$ For the initial reception of the (then) new journal and the first official contacts with certain foreign institutions and scholars, see M. D. Petruševski, "Deset godina postojanja Žive Antike" ̌̌A 10 (1960): 3-5. M. P. singles out the positive reception from the authoritative British journal The Classical Review (n.s.), 2.1.: 53, where the report concerning the new journal finishes with the words "Vivat Viva Antiquitas". 
ment is the fact that eminent philologists, historians etc. such as N. G. L. Hammond, J. Chadwick, J. Killen, C. J. Ruigh just to mention a few, appear as authors of at least one article in the journal. Concerning the interdisciplinary nature of the journal, the hopes of M. Budimir did not go unfulfilled as well - linguistics, literature, history, epigraphy, they all have their place in the journal. Of course, the separate publications (i.e. monographs) on particular topics - some of which will be discussed later - are of singular importance.

Some may object and point out that the journal was (and is) after all not a product exclusively of authors from the (S)R of Macedonia, and that the history of ancient Macedonia was not among its focal points of interest. As far as the first objection goes, since the SR of Macedonia was an integral part of the Yugoslav federation, this situation should neither surprise nor is to be construed as a disadvantage. Quite the contrary, the Yugoslav socio-cultural context acted as a stimulus for the quality of the journal, simultaneously enabling the preservation of the universal goals and values that were once emphasized by M. Budimir. It is exactly as a result of the broad-mindedness and the inclusivity of the journal since its beginnings, that today the board of editors has an international character (including not only editors from the former Yugoslav republics, but other countries as well) an essential criterion for a journal that seeks to uphold the legacy and reputation that the previous generations have attained. This is especially important in the case of Macedonia for two reasons. Firstly, given the relatively limited number of specialists in the country for such a specific and (from a chronological point) limited subject, the preservation of the journal's standing would be nearly impossible, both from a quantitative and a qualitative aspect. Secondly, if one is to consider the fact that in the time of the formation of the journal, the SR of Macedonia hardly had any classical philologists, ${ }^{10}$ it becomes quite apparent just how much this complex - and from a cultural and intellectual point extremely important - undertaking would have been impossible without the co-operation of all scholars from former Yugoslavia. At the same time, another aspect should not be neglected in the whole discussion. It was exactly because of its success and reputation that the journal created an opportunity for domestic scholars to reach out and present their ideas and findings to the wider international academic community, while simultaneously, thanks to the numerous reviews of foreign publications in it, allowing them to keep up the pace with the progress in the study of antiquity. ${ }^{11}$ Finally, no less important is the

${ }^{10}$ In that context it is important to point out that because of the lack of trained staff, up until $1956 \mathrm{M}$. Petruševski was the only professor at the Institute for Classical Philology, simultaneously giving lectures in both comparative grammar and in history of classical literature. see Ilievski, ŽA 21.1 (1971): 6 .

${ }^{11}$ Naturally, with the technological advancement in the recent decades, this aspect may seem irrelevant. However this does not in any way diminish its importance during 
socio-cultural aspect of the creation of the journal, as academic research was made more accessible to the general public in all the republics of the former federation.

The second grievance of the critics - namely, that the study of ancient Macedonia was not in the focus of the journal - may sound somewhat more convincing. There is no doubt that the reputation of the journal rested largely on the outstanding contributions in the field of classical philology, and particularly in Mycenaean studies, amongst which the work of M. D. Petruševski and P. Hr. Ilievski ${ }^{12}$ hold a singular place. Concerning Mycenaean studies, a couple of examples will suffice as an illustration of the journal's reputation. To begin with, the occurrence of numerous studies by both aforementioned scholars in the $2^{\text {nd }}$ edition of the extraordinarily important study Documents in Mycenaean Greek by M. Ventris and J. Chadwick, speaks for itself. This is all the more important since J. Chadwick points out that the list of bibliography does not pretend to be an exhaustive list of all the works related to the Mycenaean studies, but is rather selected and limited to the works referred to in the text. ${ }^{13}$ The second example of the reputation of the journal is the fact that Živa Antika is to be found amongst the abbreviations in the monumental work by P. Chantraine. ${ }^{14}$ In particular, worth mentioning is Studia Mycenaea (1988) - the $7^{\text {th }}$ special issue of Živa Antika, edited by Th. G. Palaima, C. W. Shelmerdine and P. Hr. Ilievski, names known all too well in the field of Mycenaean studies. As a final argument, it should be pointed out that the $8^{\text {th }}$ international colloquium on Mycenaean studies was held in Ohrid, SR of Macedonia, in 1985. These selected examples should be sufficient proof of the efforts and the reputation of both $\mathrm{M}$. Petruševski and P. Hr. Ilievski, as well as of the international reputation of the journal.

Admittedly, one gets the impression that Živa Antika was (or is) mainly dedicated to the field of classical philology and Mycenaean studies. In other words, it only reinforces the notion that ancient history - including that of ancient Macedonia - was not amongst the focal points of the journal. Yet, the first impression is deceptive, primarily because that assessment would do injustice to all the contributors who wrote on various problems and subjects pertaining to antiquity. As I mentioned in the introduction, any kind of a research, regardless of the

the previous decades, when for many scholars, these reviews were of paramount importance for familiarizing themselves with current developments and research.

${ }^{12}$ Similarly to M. Petruševski, P. Hr. Ilievski was a prolific philologist and scholar of world repute. Among his most important books are certainly his dissertation The $a b$ lative, instrumental and locative in the oldest Greek texts, published as a second monograph of Živa Antika in 1961. A distinguished mycenologist, his contribution to the study of the Macedonian language and in the field of Balkanology is no less substantial. see М. М. Тодоровиќ, $\check{Z} A 30$ (1980): 5-8.

${ }^{13}$ M. Ventris \& J. Chadwick, Documents..., Cambridge 1973: xiv, 595.

${ }^{14}$ P. Chantraine, Dictionnaire étymologique de la langue grecque - histoire des mots, Paris, 1968. 
actual topic, and no matter how indirectly, can contribute to a better understanding of a particular historical problem. Consequently, even an analysis of an ancient author's style - as irrelevant as it may seem to a historian - can provide a new insight into a particular debate. The fact that there were very few, if any, works concerned with the political history of ancient Macedonia or the narrative sources, does not in itself mean that the study of this topic was completely ignored. For as important as the narrative sources are, just as important is the epigraphic, numismatic and archaeological material. In fact, while studying various aspects of the life of the ancients (especially the everyday life) we rely even more on this kind of sources than we do on the narrative ones. And it is precisely in this context that the value of Živa Antika cannot be overestimated - as in almost every issue there are articles dedicated to the publishing and analysis of new inscriptions discovered on Yugoslav, and of course Macedonian territory. In particular, when it comes to the inscriptions from the SR of Macedonia, the importance of the scholar work of F. Papazoglu and B. Josifovska should be pointed out. Besides, this is not where the contribution of the Macedonian and Yugoslav scholars ends - in more than one issue there are multiple articles dedicated to archaeological finds, as well as to the study of the cults and the beliefs of the ancients who lived on the territory of the SR of Macedonia. The fact that most of these articles deal with the Hellenistic, and especially with the Roman period, cannot be taken as an indication that the scholars were not interested in the history of ancient Macedonia during its independence. After all, just as every other scholar everywhere, these scholars, i.e. their research depended, and of course still depends, on the available source material. Surely the fact that the majority of the epigraphic sources discovered in the (S)R of Macedonia dates from the Hellenistic and especially roman periods can not be turned against the researchers, that is, the choice of topics they concerned themselves with. ${ }^{15}$

That the journal was not concerned exclusively with philological research can clearly be deduced from issue XXV (1975) and XXVIII (1978). The first is a collection of articles presented on the XIII International congress of Ancient Studies, held in Dubrovnik in 1974; while the second is a collection of papers presented on the I Scholar Conference titled "Antiquity and our ancient heritage" held in Ohrid and Bitola. ${ }^{16}$ It is needless to point out the variety of subjects and problems that these two volumes encompass - history, philology, literature, ancient heritage etc. ${ }^{17}$ Naturally, the IX special issue of Živa

${ }^{15}$ After all, as Papazoglu points out: U pisanju istorije, kao i u umetnosti, materijal diktira oblik koji će se dati jednom delu. (F. Papazoglu, Srednjobalkanska plemena u predrimsko doba, Sarajevo, 1969: 7).

${ }^{16}$ The papers from the II and III gathering are published in the XXX (1980), that is the XXXIV (1984) number of the journal.

${ }^{17}$ E.g. the papers from issue XXVIII are divided into several thematic groups: linguistic and metric, literature, archaeology, and didactics. 
Antika ("Graeco-roman antiquity in Yugoslavia and the Balkans") deserves a special mention, since once again, the papers vary greatly in themes and subjects, including not only antiquity, but the ancient heritage and its resonance in the later periods. The clearest testimony of the journal's relevance to the study of ancient Macedonia is the fact that, in the first two volumes of the monumental work by N. Hammond and his collaborators (A History of Macedonia I-III), Živa Anti$k a$ is once more amongst the listed abbreviations. Finally, I doubt that most of the contemporary critics in the country are aware that one of the very few critical editions, with commentary and analysis, of the poem Historia Alexandri Magni by the mediaeval poet Quilichinus de Spoleto, was published by W. Kirsch, as the fourth special issue of $\check{Z} i$ va Antika in 1971.

As already mentioned, the importance of Živa Antika in context of the study of the history of ancient Macedonia is inextricably linked with professor F. Papazoglu, whose articles dedicated to various problems concerning ancient history, and ancient Macedonia in particular, enriched the contents of the journal for decades. A work of singular importance that deserves a special mention is her monograph Македонски градови у римско доба, published in 1957. The fact that the second edition was published almost 30 years later in French ${ }^{18}$ is an adequate indication of the extraordinary and lasting importance of this book. The publication of this book deserves a distinct mention for more than one reason. To begin with, the fact that it was the first special issue of Živa Antika, published in Skopje in 1957 - barely a decade after the end of the Second World War and a decade after the formation of the Faculty of Philosophy - must not be taken too lightly. This is very important, since the book appeared when the study of ancient Macedonia, especially of the times before Philip II and Alexander III, was still in its infancy. Even though the focus is obviously put on the cities in Roman times, the book nonetheless contains a wealth of information about the cities in pre-Roman times as well. Instead of any additional comments, I believe that an excerpt from the foreword by the author herself will be more than adequate: "I owe the greatest gratitude to the editorial board of Živa Antika for agreeing to print my work as a separate issue. Considering the well-known conditions prevailing everywhere when it comes to printing specialised literature, the publishing of no small work such as this one, illustrates the interest that our already recognized authority has for improvement of Ancient studies in our country. I am most grateful to the editor-in-chief of the journal, my friend dr. M. Petruševski, who with his characteristic selflessness and efficiency organized all the work concerning the printing and skillfully conducted it."19

${ }^{18}$ F. Papazoglu, Les villes de Macédoine a l'époque romaine, Paris, 1988 (BCH Supplément XVI).

${ }^{19}$ Ф. Папазоглу, Македонски градови у римско доба, Скопје, 1957: iii. 
Far more could be said on the importance of Živa Antika in the advancement of our knowledge in the field of classical antiquity; but I believe that on this occasion enough has been said. Still, it would be careless to end this section without saying a word or two on M. Petruševski, whose name I have mentioned in the text more than once. It would be enough to say that he is the founder of the Department for Classical Studies, as one of the founding departments of the Faculty of Philosophy in 1946, as well as that he was the first Dean of the Faculty. His contribution to the promotion and advancement of classical philology and the Mycenaean studies has already been mentioned; on this occasion, I would like to point out some other aspects of his work. Except in the field of Mycenaean studies, Petruševski gave a great contribution to our understanding of Aristotle's definition of the tragedy, with his proposed emendation of pathematon katharsin into pragmaton systasin. ${ }^{20}$ Though the solution has not been universally accepted, it is nonetheless of remarkable importance for the further study of Aristotle's definition, especially since if proven correct, it would mean a complete revision of the old and traditional understanding of classical tragedy and its purpose, based on the idea of pathematon katharsin. ${ }^{21}$ Naturally, his translations of the poems O Armatolos and Skenderbeis by $19^{\text {th }}$ century Macedonian poet G. Prličev in their original metre (and a number of valuable studies on their poetical value), are of no lesser value.

Yet if there is one accomplishment of $\mathrm{M}$. Petruševski that holds an exceptional place in his academic output - especially in the context of its cultural value - it is his translation of Homer's Iliad in the original epic hexameter. A testament to the magnitude of the effort and energy that M. Petruševski had invested in this translation is the fact that it was a problem he engaged in for more than thirty years. ${ }^{22}$ Though the publication of this translation is of everlasting importance for our country for more than one reason, on this occasion I restrict myself to only three. For the modern critics, almost exclusively interested in the history of ancient Macedonia, these next few lines will be enough: "It is in Homer's Iliad that for the first time in history are mentioned Vardar under the name of Axios, Macedonia - its regions Emathia, Pieria and Paionia and its oldest inhabitants the Paiones...

${ }^{20}$ Petruševski mentions the problem for the first time in his article „Дефиницијата на трагедијата кај Аристотела и катарсата“, Годишен зборник на Философскиот факултет I (1948): 1-17; and later expands the theory in more than one article. The whole problem and Petruševski's arguments are presented in detail in his article in $\check{Z} A 4$ (1954): 209-50.

${ }^{21} c f$. the positive remarks of T. Brunius, DHI, s.v. catharsis, 264-70.

22 The first selection from the Iliad and the Odyssey was published in 1953, followed by additional excerpts in the following years. The complete and final edition with introduction and notes was published in 1982. It was only in 2008 that the complete translation of the Odyssey was finally published, almost two decades after the death of M.P. 
Beside these, among the Paionians in the Iliad are mentioned Pelegon (i.e. Pelagon) the son of Axios and Periboia etc." ${ }^{23}$ The second and no less important reason is the fact that $\mathrm{M}$. Petruševski, in his endeavor to offer a translation that mirrors Homer - whose language, archaisms and artificiality are well known to classical philologists - as authentically as possible, frequently uses words and expressions that have long ago fallen out of use in the modern Macedonian language. In that respect, his translation of the Iliad represents an inexhaustible repository of archaisms from the Macedonian dialects that might have otherwise been forgotten and lost. But one more argument remains to be mentioned. History can undoubtedly be a teacher of life, yet it can just as well be a hindrance to progress, depending on what one seeks. For those infatuated only with the history of ancient Macedonia, this last argument bears no meaning whatsoever; yet, for those inclined to cosmopolitanism and its values, I believe that this last argument is certainly the most important - and this is the fact that there is a Macedonian translation of a timeless, unsurpassed work, which without a doubt is imprinted in the foundations of the European civilization. The fact that owing to Petruševski's masterly translation, the Macedonians are among the European nations that have the privilege to read the Ili$a d$, "that unsurpassed work of art on love and death", ${ }^{24}$ must never be forgotten.

Everything that has been said so far makes it perfectly clear that it is very hard to claim that antiquity in the SR of Macedonia was marginalized. Yet if there are still sceptics, one last argument will have to do. I already mentioned that the VIII International colloquium on Mycenaean studies was held in the SR of Macedonia in 1985. Everyone even remotely acquainted with this branch of classical philology is well aware of the importance of these gatherings; but that is not the reason why I mention this event once again. In the introductory report on the preparation of the congress, among other things, it is emphasized that the financing of the Congress was no simple task, and that it was financially supported by several international institutions and organizations. ${ }^{25}$ "However, about $65 \%$ of all the contributions came from several institutions of the Socialist Republic of Macedonia: The Republican Commission for Relations with Foreign Countries, The Community for Scientific Activities, The Macedonian Academy of Sciences and Arts, The Community for Cultural Activities, The Board of the periodical Živa Antika, and other institutions in Skopje and

${ }_{23}$ М. Петрушевски, „За Хомера и за неговата поезија“, in Хомер, Илијада, 1982: 19.

${ }^{24}$ This is a paraphrase of Budimir's concluding analysis and remarks in М. Будимир, „Хомерова песма о смрти и љубави“, іп Са балканских источника, Београд, 1969: $91 \mathrm{ff}$.

${ }^{25}$ Among them UNESCO, Conseil de la Philosophie et des Sciences Humaines and the Yugoslav Community for Scientific Activities are singled out. 
Ohrid." ${ }^{26}$ Inexplicable conduct for a country where antiquity is forgotten and ignored!

2. The fact remains, however, that as far as the study of the political history of ancient Macedonia and the narrative sources goes, in the more traditional sense of historical knowledge, little was done in the SR of Macedonia. Once again, this phenomenon is attributed to the neglect and disinterest for this field of study in the former country. To what extent this conclusion is valid or not, is a question that can hardly be answered with certainty, especially since most of the leading figures at that time are no longer with us. But for our purpose, this is not too important: I leave the answer to those more involved in the analysis of the cultural and intellectual policies of former Yugoslavia. I would rather draw the attention of the reader to some other factors that influenced the relatively slow development of the study of ancient Macedonia independently of the political and intellectual climate.

First and foremost, it must be pointed out that the disregard for the study of the (primarily political) history of ancient Macedonia is not a phenomenon specific to the former state, but can be seen as a more or less general feature in the scholar world on international level. A brief analysis of the contents of the first edition of the Cambridge Ancient History will be enough to note that there is barely any mention of ancient Macedonia until the times of Philip II and Alexander III. A detailed analysis of this situation would require far more than 15 pages, and therefore I will restrict myself to only a handful of reasons. ${ }^{27}$

The first, and fundamental problem, is of course the problem of the sources: the ancient Macedonians, like so many other ancient peoples, left behind no literature to speak of. ${ }^{28}$ To make things even more complicated, even the narrative sources that are available, more often than not come from their antagonists; ${ }^{29}$ it is therefore very difficult to

${ }^{26}$ Report on the eight colloquium: 5, in P. Hr. Ilievski \& L. Crepajac (edd.), Tractata Mycenaea. Proceedings of the eight international colloquium on Mycenaean studies, held in Ohrid, 15-20 September 1985, Skopje, 1987.

${ }^{27}$ For an excellent overview of this particular problem see E. N. Borza, "The History and Archaeology of Macedonia: Retrospect and Prospect", in B. Barr-Sharrar \& E. N. Borza (edd.): Macedonia and Greece in Late Classical and Early Hellenistic Times, Washington, 1982: 17-30.

${ }^{28}$ Or to be more precise, it is not that there were no works written by ancient Macedonians, but none of those sources have survived through the ages. It is interesting to note that F. Jacoby, in his edition of the fragments from the lost Greek historians, identifies only 13 possible historiographers of ancient Macedonia. For a convenient overview of the problem see P. J. Rhodes „The Literary \& Epigraphic Evidence to the Roman Conquest “ in J. Roisman \& I. Worthington (edd.): A Companion to Ancient Macedonia, 2010: 23-40.

${ }^{29}$ E. N. Borza, Before Alexander: constructing Early Macedonia, Claremont, 1999: 5: „Like the Carthaginians and the Spartans, the Macedonians are among the silent people of the ancient Mediterranean basin. Almost everything we know about them derives from the written accounts of others, and - as in the case of the Carthaginians and the Spartans - those written accounts were either not well-informed or they were hostile, and occasionally both." 
build a clear and consistent perception of the ancient Macedonians. Moreover, the inscriptions pertaining to the history of ancient Macedonia from pre-Roman times are relatively few in number, ${ }^{30}$ especially concerning the period before Philip II. ${ }^{31}$ The situation is a bit more favorable for the history of Macedonia in Hellenistic times, but it is still far from satisfactory and incomparably more limited than in the case of the Seleucid or the Ptolemaic kingdoms. In his exceptional Social and Economic history of the Hellenistic World, M. Rostovtzeff dedicates approximately 200 pages on the conditions in the Ptolemaic state, more than 100 pages on the Seleucid state, and only five pages on Antigonid Macedonia. Since the days of Rostovtzeff the corpora of sources have greatly increased - primarily in inscriptions - and our knowledge and understanding of ancient Macedonia and its institutions has expanded. ${ }^{32}$ However, the fact remains that when it comes to the sources, amongst the three great Hellenistic monarchies, the Antigonids are still the ones that are most problematic.

The next two problems are somewhat interconnected. The activities over the last half a century have shown just how "fertile" from an archaeological point of view the territory of ancient Macedonia is, and it is therefore no surprise that almost every year new discoveries are published. Yet, with a few exceptions, for a long time this area was not in the focus of the archaeologists. ${ }^{33}$ Fascinated by the achievements of classical Greece and Rome, the academic effort was focused on those areas and periods; as R. Errington points out, the focus was turned towards Athens, which dominates the literary tradition and has been synonymous with Greek history for too long. ${ }^{34}$ In fact, only from the middle of the past century the focus started shifting more towards the peripheral areas and the peoples that lived on the fringes of the ancient Greco-Roman world. The second problem arises from the (then) contemporary political borders of the Balkans, as well as the different political and ideological climate, which hampered the collective and systematic research of the archaeological material; as N. G. L. Hammond points out in the introduction to the first volume of the History

${ }^{30}$ I do not mean to imply that there are none at all, but compared, for example, to the number of inscriptions from Athens, they do seem negligible.

${ }^{31}$ P. J. Rhodes, "Evidence...": 33f.: "The Macedonian kings never developed the habit of publishing documents as Greek states did. There are very few inscriptions of any kind from Macedonia or cities and other units within it of the classical period. Some are from the Hellenistic period but most are later than AD 100, and for the classical and Hellenistic periods covered by this chapter many of the significant texts come not from Macedonia itself but from Greek states as a result of their dealings with the Macedonians."

${ }^{32}$ For an overview of the progress till the end of the $20^{\text {th }}$ century see R. M. Errington, "Recent Research on Ancient Macedonia", Analele Univ. Galaţi s. Istorie 1 (2002): $9-21$.

${ }^{33}$ For an overview of the archaeological activities on the territory of ancient Macedonia, see Borza, "History and Archaeology...": $21 \mathrm{ff}$.

${ }^{34}$ Errington, "Recent Research...": 9f. 
of Macedonia, one could get an impression that Yugoslav, Greek and Albanian archaeologists were excavating on separate planets. ${ }^{35}$

This does not mean that the history of ancient Macedonia was completely ignored; however, in most cases the accounts were focused on special periods and topics, which is another reason that hampered the development of a synthetic history of ancient Macedonia. ${ }^{36}$ In that context, it might be worth mentioning that at the I International Symposium on Ancient Macedonia, held in Thessaloniki, C. F. Edson's important paper on early Macedonia before Philip II was presented. ${ }^{37}$ The fact that the paper is approximately 30 pages long, clearly illustrates the state of knowledge about Macedonia at the time. ${ }^{38}$ However, at the same time, it is with the end of the $60 \mathrm{~s}$ and the beginning of the 70 s that a more systemic and thorough research on the history of ancient Macedonia begins, not only of Philip II and Alexander III, but just as much of their predecessors and successors. ${ }^{39}$ Accordingly, it is no surprise that already in 1972 the first volume of Hammond's monumental work was published. ${ }^{40}$

These are some of the reasons for the relatively slow development of the study of ancient Macedonia. Needless to say, this is not an attempt to vindicate the shortcomings of the academic production in the previous state, nor deny that the political and ideological factors had any bearing on the problem. However I do hope that, at the same time, I have shown that the study of antiquity, including the study of ancient Macedonia was hardly a barren wasteland, and that the position that nothing at all was done cannot be maintained. This is especially important when discussing archaeology ${ }^{41}$ and classical philology, where in national terms the accomplishments were significant. This is all the more important since a thorough knowledge in both these fields is a necessary prerequisite for the study of the history of antiquity, including the history of ancient Macedonia. In other words, even though the study of ancient Macedonia may not have been a focal point in the historical production, it was exactly during the time of the SR of Macedo-

${ }^{35}$ N. G. L. Hammond, A History of Macedonia, v.1: viii.

${ }^{36}$ Borza "History and Archaeology...": 24.

${ }^{37}$ C. F. Edson, "Early Macedonia", Ancient Macedonia I, Thessaloniki, 1970: 17-44.

${ }^{38} \mathrm{I}$ must point out that this is in no way an attempt to diminish the great value of the article, which even after all this time and progress, still contains stimulating and illuminating analysis.

${ }^{39}$ Though it may be of interest to point out Borza's remark that even in the 1980s in some circles the study of the history of ancient Macedonia still started with Philip II (E. N. Borza, In the Shadow of Olympus: the emergence of Macedon, Princeton, 1990: 199 n.4).

${ }^{40}$ N. G. L. Hammond, A History of Macedonia, vol.1, Oxford, 1972. The second volume was written in collaboration with G. T. Griffith (1979), and the third with F. W. Walbank (1988).

${ }^{41}$ In order to avoid needless repetitions, it was agreed that the archaeological aspect will be more thoroughly covered by my colleague D. Stojanov, whose work on the same project appears in this issue of the journal. 
nia that the foundations for a further and in-depth study of this subject were laid down. An excellent example that illustrates this point is the increased production of translations from classical languages from the late 1980s and the early 1990s, including a number of historiographical works; as well as the publication of a number of synthetic works in the field of archaeology. The progress during the past three decades should neither surprise, nor be interpreted as something completely new, without its roots in the past and not having any continuity with the academic production from the times of the SR of Macedonia. 
